\title{
Plaque Purification of Bluetongue Virus Serotype-4 (BTV-4)
}

\author{
M. Srikanth Reddy ${ }^{1}$, Kalyani Putty ${ }^{1 *}$, Y. Narasimha Reddy ${ }^{1}$, P.P. Rao ${ }^{2}$, \\ M. Ramakoti Reddy ${ }^{3}$, Uma $^{2}$, Sunil R. Patil ${ }^{1}$, Susmitha Birru ${ }^{1}$, \\ Abdul Muzeer Shaik ${ }^{1}$ and Dhanalakshmi Kancharlapally ${ }^{1}$
}

${ }^{1}$ College of Veterinary Science, Rajendranagar, Hyderabad-500030, Telangana, India

${ }^{2}$ Ella Foundation, Genome Valley Hyderabad-500 078, Telangana, India

${ }^{3}$ Directorate of Poultry Research, Rajendranagar, Hyderabad-500030, Telangana, India

*Corresponding author

\section{A B S T R A C T}

\begin{tabular}{|c|}
\hline Keywords \\
\hline $\begin{array}{l}\text { BTV-4, Vero cells, } \\
\text { TCID50, Plaque } \\
\text { purification, Sea plaque } \\
\text { agarose, RT-PCR }\end{array}$ \\
\hline Article Info \\
\hline $\begin{array}{l}\text { Accepted: } \\
23 \text { March } 2018 \\
\text { Available Online: } \\
10 \text { April } 2018\end{array}$ \\
\hline
\end{tabular}

\section{Introduction}

Bluetongue (BT) an infectious, noncontagious viral disease of sheep and other domestic and wild ruminants caused by bluetongue virus (BTV), is a segmented double-stranded RNA virus of genus Orbivirus under family Reoviridae. Segmented genome facilitates genetic reassortment between different serotypes and strains. At present 27 distinct BTV serotypes have been recognized worldwide with the possible addition of two more serotypes (Hofman et al., 2008; Maan et al., 2011; Zientara et al., 2014). In India, 23 serotypes
The present study was taken up with a view to undertake plaque purification of BTV-4 isolate available in the department, to confirm its purity. BTV-4 isolate was adapted to Vero cell line and had a titer of $10^{6.46} / \mathrm{ml}$ after 8 passages in the process of plaque purification which was determined as $10^{4.833} / \mathrm{ml}$ prior to adaption. Plaque purification was carried for three times using agarose overlaying method in 6 well plate. Each time plaques were observed from $4^{\text {th }}$ day of infection of approximately not more than $1 \mathrm{~mm}$ diameter. One of the plaques from third round of purification was grown in $\mathrm{T}_{25}$ flask and the resultant cell culture fluid was used for RNA isolation and RT-PCR through which the respective plaque was confirmed as BTV-4. Therefore, it was confirmed that there was no ther serotype other than BTV-4 and the plaque purified virus can be used either to study pathogenesis or to raise hyperimmune serum.

have been recognized based on serology, among them 14 serotypes viz., BTV-1, 2, 3, 4, $6,9,10,1216,17,18,21,23$ and 24 have been isolated (AINP-BT, 2012; Rao et al., 2014; Krishnajyothi et al., 2016).

Due to a large number of susceptible hosts, BTV serotypes and Culicoides vectors; control of BT is a challenge. Therefore, effective control of BT disease requires proper diagnosis (Reddy et al., 2010). A preliminary diagnosis of BT disease is usually done by epidemiology, clinical sign and post-mortem finding (Afshar, 1994). Proper diagnosis involves isolation of virus then standard 
serological and molecular confirmation. But, due to limitations of serological and molecular techniques, a combination of Reverse transcription polymerase chain reaction (RTPCR) with Virus neutralization test (VNT) may provide better results for which plaque purification of the samples is necessary (Reddy et al., 2015). Hence, the current study was undertaken with an aim to plaque purify BTV4 isolated from BT outbreaks in Andhrapradesh during 2015.

\section{Materials and Methods}

\section{Adaptation of BTV-4 to Vero cell line}

BHK-21 cell line adapted BTV-4 serotype was passaged four times in Vero cells using Minimum Essential Medium (MEM) with 1\% Fetal Bovine Serum (FBS). After fourth passage, BTV-4 serotype strength was determined in terms of tissue culture infective dose 50 (TCID50) in 96 well tissue culture plate.

After molecular confirmation, virus titer was calculated once again to know whether there was any increase in TCID50 as it was passaged 7 times more after Vero Cell line adaptation during plaque purification. Virus titer was calculated according to Reed and Munch method (1938).

\section{Plaque purification of BTV}

Plaque purification was carried out in 6-well tissue culture plates using agarose overlaying method. Each well was seeded with $3 \mathrm{ml}$ of growth medium (MEM with 10\% FBS) containing Vero Cells $\left(4 \times 10^{6}\right.$ Vero cells per plate) and kept in incubator with $5 \% \mathrm{CO}_{2}$ at $37^{\circ} \mathrm{C}$. After attaining $80-90 \%$ confluence, BTV-4 was serially diluted from $10^{-1}$ to $10^{-6}$ in plain medium. After discarding growth medium from six well plate, monolayer of five wells were infected with $1 \mathrm{ml}$ of different virus dilutions starting from $10^{-2}$ to $10^{-6}$ whereas $6^{\text {th }}$ well was kept as cell control and kept in incubator with $5 \% \quad \mathrm{CO}_{2}$ at $37^{\circ} \mathrm{C}$ for $1 \mathrm{hr}$. involving swaying for every 10-15 minutes to ensure virus adsorption. After $1 \mathrm{hr}$. incubation, inoculum was drained off completely without disturbing the monolayer and each well was immediately overlaid with $3 \mathrm{ml}$ of $2 \mathrm{X}$ MEM with $10 \%$ FBS; $2.6 \%$ sea plaque agarose (Cambrex Bio Science, Cat.No.50100) mixture in 1:1 ratio. This draining off and overlaying was carried out for one well for each time instead of discarding all wells at a time to counter drying of monolayer as overlaying was done slowly. Thus, overlaid plates were allowed to solidification and then transferred to incubator. Plaques with more discretion from others were collected with the help of micropipette in $200 \mu \mathrm{l}$ of growth medium with $10 \%$ FBS. Collected plaques were infected to Vero cell monolayers in 12well plate to check whether those of virus origin or dead cells. Infected monolayers of 6well tissue culture plate were stained with $1 \%$ crystal violet to observe plaques with unaided eye.

\section{Molecular investigation}

\section{Genome extraction}

Randomly one plaque was selected from third round of plaque purification and infected to $\mathrm{T}_{25}$ flask. BTV genome i.e., double strand RNA (ds RNA) was extracted from cell culture fluid by Acid Phenol method using Trizol $^{R}$ reagent and after confirmation the same was used for polymerase chain reaction.

\section{Reverse Transcription Polymerase Chain Reaction (RT-PCR)}

Complementary DNA (cDNA) was synthesized using a total of $30 \mu 1$ reaction mixture $(10 \mu 1$ of RNA, $9 \mu$ l of RT mix; $11 \mu \mathrm{l}$ of nuclease free water). 
First, RNA mix was denaturated at $95^{\circ} \mathrm{C}$ for 5 minutes followed by snap cooling for 5 minutes. Meanwhile RT mix was prepared and stored at $4^{\circ} \mathrm{C}$ until RNA denaturation. After snap cooling, RT mix was added to denatured RNA mix and subjected to following conditions in PCR thermo cycler with the following conditions: $25^{\circ} \mathrm{C} / 10$ minutes, $42^{\circ} \mathrm{C} / 1$ hour, $72^{\circ} \mathrm{C} / 10$ minutes, Hold at $4^{\circ} \mathrm{C}$.

\section{PCR}

Polymerase chain reaction for plaque purified virus was carried out with primers (IDT-DNA) specific for available bluetongue virus serotypes (BTV-1, 2, 4, 9, 10, 12, 16, 21, 23, 24) (Reddy et al., 2015) along with positive and negative controls for each serotype.

\section{Results and Discussion}

\section{Adaptation of virus}

During adaptation, in the first two passages, cytopathic effect (CPE) as rounding, clumping of dead cells and complete peeling off monolayer (Fig. 1) was observed 4-5 days post infection (dpi.) whereas in the following two passages time taken for complete CPE was only 3 dpi. Virus titer in terms of TCID50 was calculated as $10^{3.833} / 100 \mu \mathrm{l}$ (or) $10^{4.833} / \mathrm{ml}$.

\section{Plaque purification}

Plaques of approximately not more than $1 \mathrm{~mm}$ in diameter were first identified after 3 dpi. (Fig. 2A) which became more prominent from $4^{\text {th }}$ day onwards as restricted CPE areas showing dead cells scattering light surrounded by healthy monolayer (Fig. 2B). Plaques collected from 6-well plate infected to 12-well plate also showed CPE within 3 dpi., therefore confirming that collected plaques contained infectious virus.

Number of plaques was observed to decrease as dilution of virus increased which could be observed best at a glance after staining with $1 \%$ crystal violet solution (Fig. 3 ).

Among wells infected with $10^{-2}$ to $10^{-6}$ virus dilutions, only $10^{-2}$ to $10^{-4}$ dilutions produced plaques whereas monolayer infected with $10^{-5}$ and $10^{-6}$ dilutions revealed no plaques similar to uninfected well.

\section{Molecular confirmation}

Gel electrophoresis of RNA extracted from plaque purified BTV-4 infected cell culture fluid revealed clear segmented nature of genome (Fig. 4) which was then used in RTPCR confirmation.

Gel electrophoresis of PCR products showed specific PCR amplicon of 464bp with BTV-4 serotype specific primers but did not give any amplification with remaining serotype specific primers (Fig. 5 and 6; Table 1). Thus, the isolate was confirmed as BTV-4 serotype. Finally, TCID50 of the RT-PCR confirmed virus was calculated as $10^{5.46} / 100 \mu \mathrm{l}$ (or) $10^{6.46} / \mathrm{ml}$.

\section{PCR conditions followed in thermo cycler}

For BTV-1,2,4,9,10,12,21,23,24

$94^{0} \mathrm{C}$ for 3 minutes

$94^{\circ} \mathrm{C}$ for 30 second

$55^{\circ} \mathrm{C}$ for 30 seconds 35 cycles

$68^{\circ} \mathrm{C}$ for 2 minutes

$68^{\circ} \mathrm{C}$ for 10 minutes
For BTV-16:

$94^{\circ} \mathrm{C}$ for 3 minutes $94^{\circ} \mathrm{C}$ for 30 seconds

$50^{\circ} \mathrm{C}$ for 30 seconds

$68^{\circ} \mathrm{C}$ for 2 minutes

35 cycles

PCR thermo cycler was set to hold at $4^{\circ} \mathrm{C}$ after completion of reaction. 
1.A

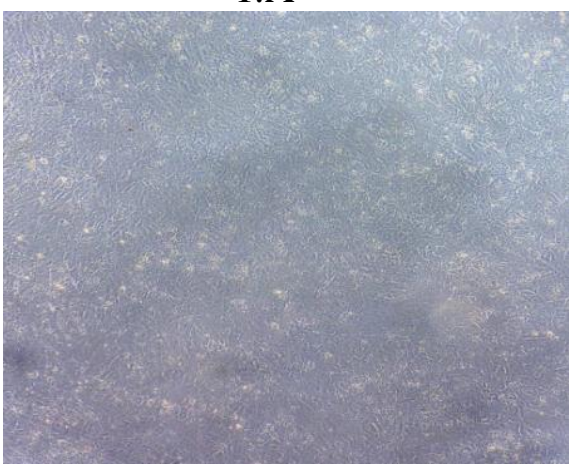

1.B

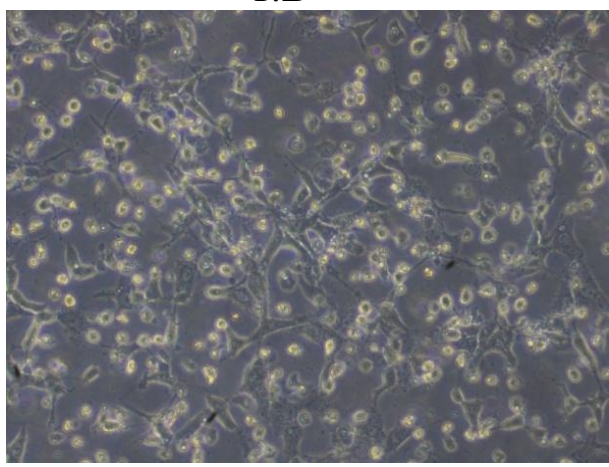

Figure 1: Propagation of BTV4 in Vero Cell line

1.A shows mock infected cell line exhibiting no CPE, whereas 1.B shows BTV 4 infected cell line on $5^{\text {th }}$ day post infection showing characteristic CPE (40X).

2.A

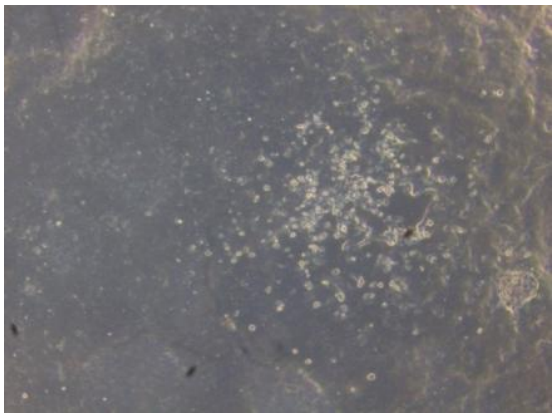

2.B

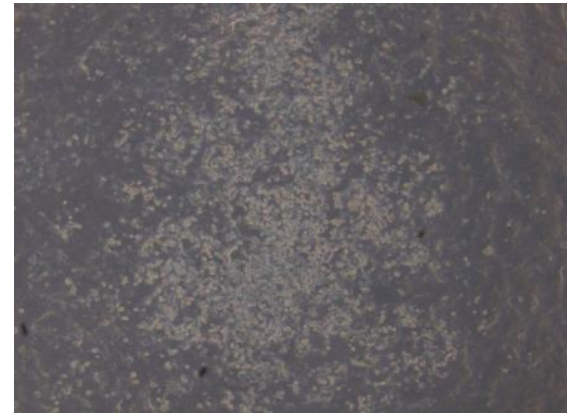

Fig 2: Plaques of BTV 4 as seen under inverted microscope (40X).

Fig 2 A shows single individual plaque surrounded with confluent healthy monolayer.

Fig 2B shows spreading plaque

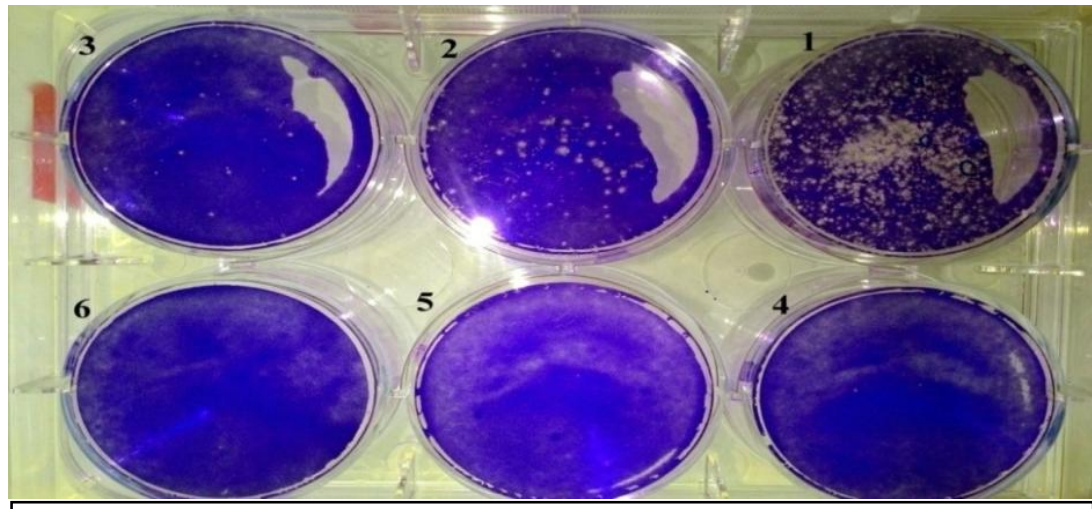

Fig 3: Crystal violet staining of monolayer showing plaques.

In above stained plate, wells numbered 1 to 5 were infected with $10^{-2}$ to $10^{-6}$ dilutions of virus, respectively and well no. 6 was kept as control i.e., infected with plain MEM. Plaques can be seen as white areas. 


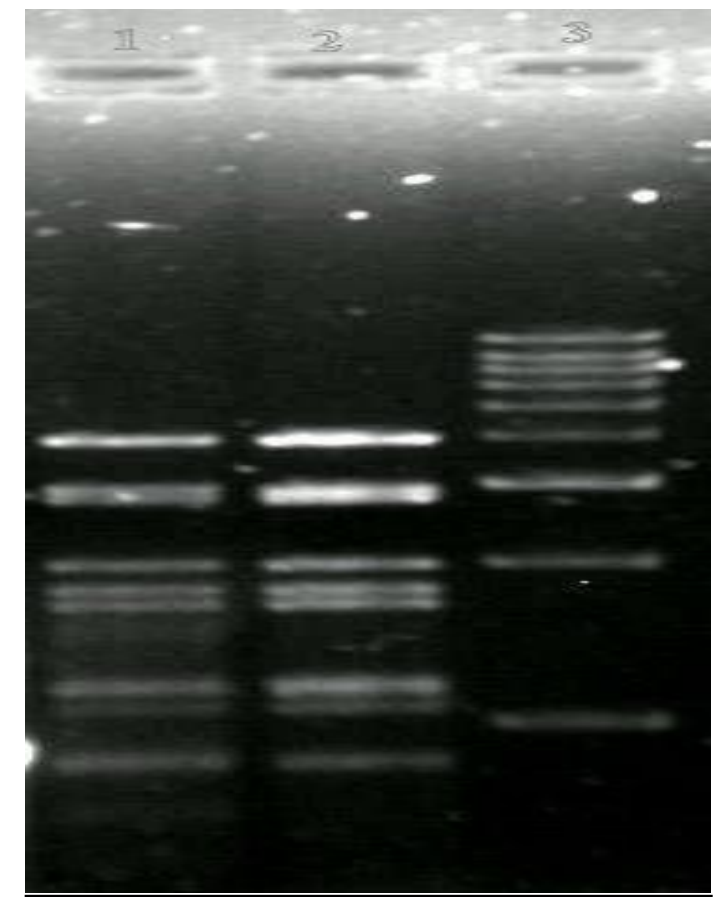

Fig. 4: Ten (10) segmented ds RNA pattern of BTV 4 genome.

Lane $1 \& 2$ shows ten segmented pattern of BTV4 that was purified from two different plaques.

Lane 3 is 100 bp DNA ladder.

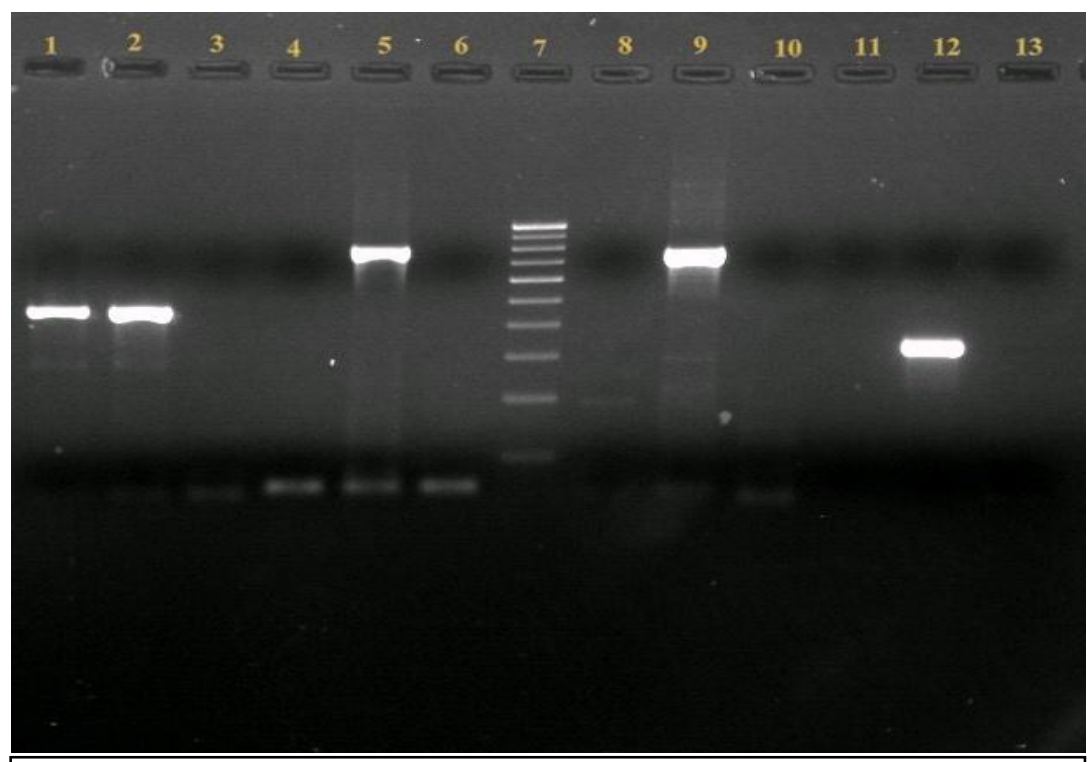

Fig 5: Molecular confirmation of BTV 4

Plaque purified BTV 4 was confirmed as BTV 4 when PCR amplicon was observed with BTV 4 specific primers but not with BTV 10,12 and 24 specific primers. 


\begin{tabular}{|l|l|l|}
\hline $\begin{array}{l}\text { Lane 1: Sample cDNA } \\
\text { with BTV-4 primers }\end{array}$ & $\begin{array}{l}\text { Lane 2: Positive control } \\
\text { for BTV-4: } 464 \mathrm{bp}\end{array}$ & $\begin{array}{l}\text { Lane 3: Negative } \\
\text { control }\end{array}$ \\
\hline $\begin{array}{l}\text { Lane 4: Sample cDNA } \\
\text { with BTV-10 primers }\end{array}$ & $\begin{array}{l}\text { Lane 5: Positive control } \\
\text { for BTV-10: } 800 \mathrm{bp}\end{array}$ & $\begin{array}{l}\text { Lane 6: Negative } \\
\text { control }\end{array}$ \\
\hline & Lane 7: 100 bp ladder & \\
\hline $\begin{array}{l}\text { Lane 8: Sample cDNA } \\
\text { with BTV-12 primers }\end{array}$ & $\begin{array}{l}\text { Lane 9: Positive control } \\
\text { for BTV-12: } 750 \mathrm{bp}\end{array}$ & $\begin{array}{l}\text { Lane 10: Negative } \\
\text { control }\end{array}$ \\
\hline $\begin{array}{l}\text { Lane 11: Sample cDNA } \\
\text { with BTV-24 primers }\end{array}$ & $\begin{array}{l}\text { Lane 12: Positive control } \\
\text { for BTV-24: } 319 \mathrm{bp}\end{array}$ & $\begin{array}{l}\text { Lane 13: Negative } \\
\text { control }\end{array}$ \\
\hline
\end{tabular}

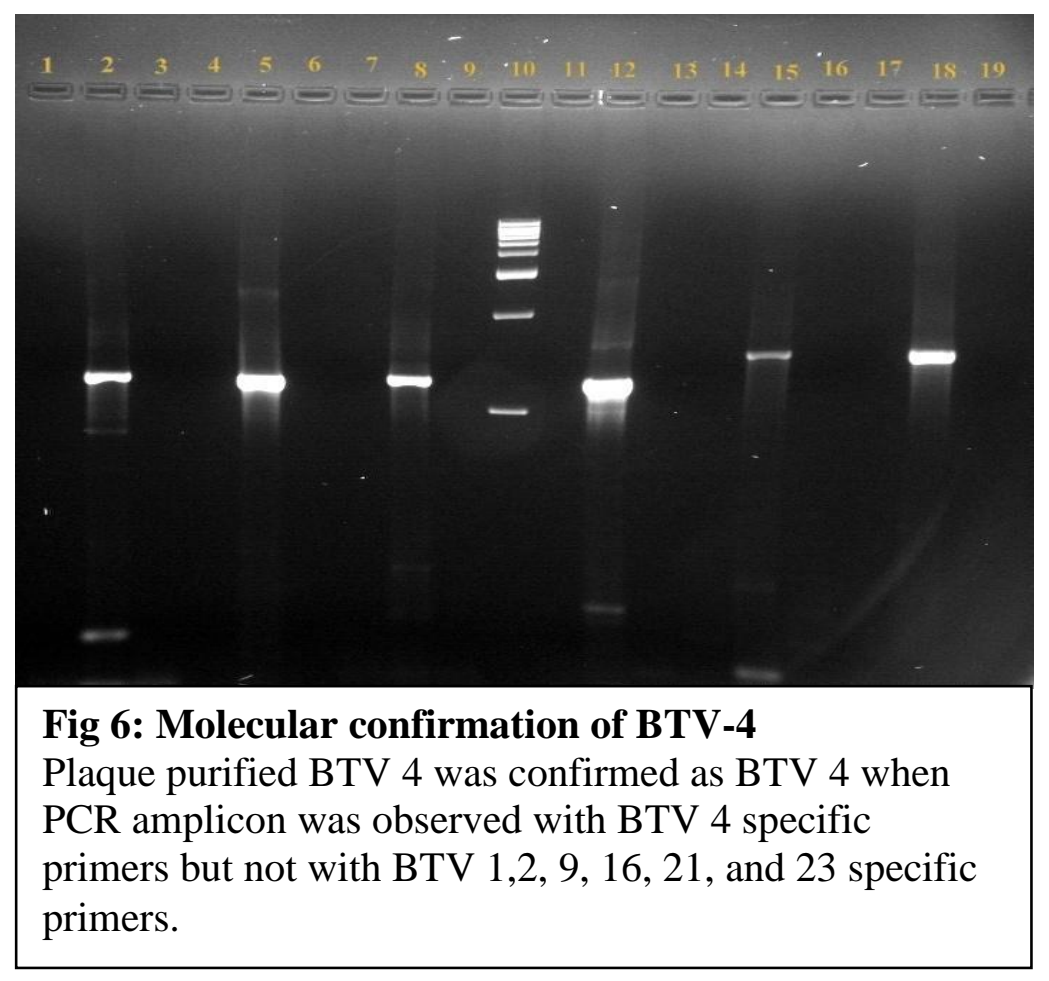

\begin{tabular}{|c|c|c|}
\hline $\begin{array}{l}\text { Lane 1:Sample cDNA } \\
\text { with BTV-1 primers }\end{array}$ & $\begin{array}{l}\text { Lane 2: Positive control } \\
\text { for BTV-1: } 1179 \mathrm{bp}\end{array}$ & $\begin{array}{l}\text { Lane 3: } \\
\text { Negative } \\
\text { control }\end{array}$ \\
\hline $\begin{array}{l}\text { Lane 4:Sample cDNA } \\
\text { with BTV-2 primers } \\
\end{array}$ & $\begin{array}{l}\text { Lane 5: Positive control } \\
\text { for BTV-2: } 1172 \mathrm{bp}\end{array}$ & $\begin{array}{l}\text { Lane 6: } \\
\text { Negative control }\end{array}$ \\
\hline $\begin{array}{l}\text { Lane 7:Sample cDNA } \\
\text { with BTV-9 primers }\end{array}$ & $\begin{array}{l}\text { Lane 8: Positive control } \\
\text { for BTV-9: } 1200 \mathrm{bp}\end{array}$ & $\begin{array}{l}\text { Lane 9: } \\
\text { Negative control }\end{array}$ \\
\hline \multicolumn{3}{|c|}{ Lane 10: $1 \mathrm{kbp}$ ladder } \\
\hline $\begin{array}{l}\text { Lane 11:Sample cDNA } \\
\text { with BTV-16 primers }\end{array}$ & $\begin{array}{l}\text { Lane 12: Positive control } \\
\text { for BTV-16: } 1200 \mathrm{bp}\end{array}$ & $\begin{array}{l}\text { Lane 13: } \\
\text { Negative control }\end{array}$ \\
\hline $\begin{array}{l}\text { Lane 14: Sample cDNA } \\
\text { with BTV-21 primers }\end{array}$ & $\begin{array}{l}\text { Lane 15: Positive control } \\
\text { for BTV-21: } 1388 \mathrm{bp}\end{array}$ & $\begin{array}{l}\text { Lane 16: } \\
\text { Negative control }\end{array}$ \\
\hline $\begin{array}{l}\text { Lane 17: Sample cDNA } \\
\text { with BTV-23 primers }\end{array}$ & $\begin{array}{l}\text { Lane 18: Positive control } \\
\text { for BTV-23: } 1370 \mathrm{bp}\end{array}$ & $\begin{array}{l}\text { Lane 19: } \\
\text { Negative control }\end{array}$ \\
\hline
\end{tabular}


Table.1 Primers sequence ( $\left.5^{\prime}-3^{\prime}\right)$ used for PCR

\begin{tabular}{|c|c|c|}
\hline $\begin{array}{l}\text { Bluetongue } \\
\text { virus serotype }\end{array}$ & Primer & Sequence \\
\hline \multirow[t]{2}{*}{ BTV-1 } & $\mathrm{F}$ & 5 TGT CGA GCC GAT TGA AGA TCC GTC 3. \\
\hline & $\mathrm{R}$ & 5 ATC GTC ATT CCG TCG TTG TGC G 3’ \\
\hline \multirow[t]{2}{*}{ BTV-2E } & $\mathrm{F}$ & 5 TAC GCA CCT CGT GAG AGA GA 3’ \\
\hline & $\mathrm{R}$ & 5 GTT GGA GGA ACC AAC TTC CA 3' \\
\hline \multirow[t]{2}{*}{ BTV-4 } & $\mathrm{F}$ & 5 GTT GGA TCT GAG AAA TGG GT 3’ \\
\hline & $\mathrm{R}$ & 5 AAG ACA CGG ATA AGG ATT CG 3 \\
\hline \multirow[t]{2}{*}{ BTV-9E } & $\mathrm{F}$ & 5 GAT GGA ACG GCT AAA CCA AA 3’ \\
\hline & $\mathrm{R}$ & 5 TGG ATA TTT GAC ACG AGC GA 3' \\
\hline \multirow[t]{2}{*}{ BTV-10 } & $\mathrm{F}$ & 5 TGT ATC GTT AAG GCG AGG TCA GCA 3’ \\
\hline & $\mathrm{R}$ & 5 TGT CTT CTA ACG GCC TCT CAC G 3 \\
\hline \multirow[t]{2}{*}{ BTV-12 } & $\mathrm{F}$ & 5 TTT AGG TGA CCA TGT GGA GAC G 3’ \\
\hline & $\mathrm{R}$ & 5 CAA CGC ACT TTC GCA AAA CC 3 \\
\hline \multirow[t]{2}{*}{ BTV-16 } & $\mathrm{F}$ & 5 TCG AGG AAA GCG GAT ACC ACG T 3' \\
\hline & $\mathrm{R}$ & 5 CGT TGC GCT AAC TCG ACT TCG C 3’ \\
\hline \multirow[t]{2}{*}{ BTV-21 } & $\mathrm{F}$ & 5 GCA GAT TCG TAC AAC CAA CGG CC 3' \\
\hline & $\mathrm{R}$ & 5 TTG GGA TTT GCG AGG CGC GA 3’ \\
\hline \multirow[t]{2}{*}{ BTV-23 } & $\mathrm{F}$ & 5 GCG TTG CGA TGG ATG AGT TAG CA 3’ \\
\hline & $\mathrm{R}$ & 5 GGT GGT CAT CTC TTC ATC TTC GGG G 3 \\
\hline \multirow[t]{2}{*}{ BTV-24 } & $\mathrm{F}$ & 5 GTT TCA TGA ATT TGA AGG ACG 3' \\
\hline & $\mathrm{R}$ & 5 ACC TTG TGA AAT CTT AGT YTT TG 3. \\
\hline
\end{tabular}

(Reddy et al., 2015)

Identifying of plaques in the current study can be correlated with the observations of Howell et al., (1967) and Dulbecco (1952). The incubation time for plaque development is higher when compared with Cooper's (1962) study in which plaques were produced within $40 \mathrm{hrs}$ of incubation. This could be attributed to his modified basic method i.e., agar-cell suspension and different virus in a different cell line.

The small size of plaques might be due to increased agarose concentration (1.2\%) in overlay as observed by Howell et al., (1967) but clear demarcation of plaques from surrounding healthy monolayer was observed using $10 \%$ FBS. This observation was same as Blanchard and Stott (1989) studies. Further, almost parallel results were obtained with Howell (1967) and Dulbecco (1952) with regard to linear relationship between number of plaques and virus concentration inoculated to monolayer.
Amplification of partial VP2 in plaque purified BTV 4 with expected size of $464 \mathrm{bp}$ was observed only with BTV-4 specific primers and is in accordance with the conclusions of Rodriguez-Sanchez et al., (2010) and Dadawala et al., (2013) regarding VP2 based serotypespecific RT-PCR.

BTV-4 was successfully plaque purified in Vero cells which can be used further in serological or pathogenesis studies. Also, increase in virus titre was observed from $10^{3.833} / 100 \mu \mathrm{l}$ (or) $10^{4.833} / \mathrm{ml}$ to $10^{5.46} / 100 \mu \mathrm{l}$ (or) $10^{6.46} / \mathrm{ml}$ with serial passages.

\section{Acknowledgments}

The authors acknowledge Department of Biotechnology, Government of India, for funding the study (BT/PR9711/ADV/ 90/158/2013). 


\section{References}

Afshar A 1994 Bluetongue: laboratory diagnosis. Comparative immunology, microbiology and infectious diseases 17: 221-242.

AINP-BT 2012 Annual Report, All India Network Project on Bluetongue. Indian Council of Agricultural Research, New Delhi, India.

Blanchard-Channell M and Stott J L 1989 Bluetongue virus propagation and plaque assay: variation due to medium and serum supplement. Journal of virological methods 24: 265-274

Cooper P D 1962. The plaque assay of animal viruses. Advances in virus research 8: 319-378.

Dadawala A I, Kher H S, Chandel B S, Bhagat A G, Chauhan $\mathrm{H}$ C, Ranjan $\mathrm{K}$ and Minakshi P 2013 Isolation and molecular characterization of bluetongue virus 16 of goat origin from India. Advances in Animal and Veterinary Sciences 1: 24-29.

Dulbecco R 1952 Production of plaques in monolayer tissue cultures by single particles of an animal virus. Proceedings of the National Academy of Sciences 38: 747-752.

Hofmann M A, Renzullo S, Mader M, Chaignat V, Worwa G and Thuer B 2008 Genetic characterization of toggenburg orbivirus, a new bluetongue virus, from goats, Switzerland. Emerg Infect Dis, 14: 18551861.

Howell P G, Verwoerd D W and Oellermann R A 1967 Plaque formation by bluetongue virus. The Onderstepoort journal of veterinary research 34: 317-332.

Krishnajyothi, Y, Maan S, Kandimalla K, Maan N S, Tutika R B, Reddy Y V and Ahmed S M 2016 Isolation of Bluetongue Virus 24 from India-An Exotic Serotype to
Australasia. Transboundary and emerging diseases. 63: 360-364.

Maan S, Maan N S, Nomikou K, Veronesi E, Bankowska BK, Manjunatha N, Attoui H, Mertens PPC 2011 Complete Genome characterization of a novel 26th Bluetongue virus serotype from Kuwait. PLoS One. 6: e26147.

Rao PP, Hegde NR, Reddy YN, Krishnajyothi Y, Reddy YV, Susmitha B, Gollapalli SR, Putty K and Reddy GH 2014 Epidemiology of Bluetongue in India. Transbound. Emerg. Dis. 10.1111/tbed. 12258 .

Reddy Y K M, Manohar BM, Pandey AB, Reddy YN, Prasad G, Chauhan RS 2010 Development and evaluation of inactivated pentavalent adjuvanted vaccine for Bluetongue. Indian Vet. J. 87: 434-436.

Reddy Y V, Krishnajyothi Y, Susmitha B, Devi B V, Brundavanam Y, Gollapalli S R K and Rao P P 2015 Molecular Typing of Bluetongue Viruses Isolated Over a Decade in South India. Transboundary and emerging diseases 10.1111/tbed. 2320.

Reed L J and Muench H 1938 A Simple Method of Estimating Fifty Per Cent Endpoints. American Journal of Epidemiology 27: 493-497.

Rodríguez-Sánchez B, Gortázar C, Ruiz-Fons F and Sánchez-Vizcaíno J M 2010 Bluetongue virus serotypes 1 and 4 in red deer, Spain. Emerg Infect Dis 16: 518520.

Zientara S, Sailleau C, Viarouge C, Höper D, Beer M, Jenckel M, Hoffmann B, Romey A, Bakkali-Kassimi L, Fablet A, Vitour D and Bréard E 2014 Novel bluetongue virus in goats, Corsica, France. Emerg. Infect. Dis. 20: 2123-2132.

\section{How to cite this article:}

Srikanth Reddy M., Kalyani Putty, Y. Narasimha Reddy, P.P. Rao, M. Ramakoti Reddy, Uma, Sunil R. Patil, Susmitha Birru, Abdul Muzeer Shaik and Dhanalakshmi Kancharlapally. 2018. Plaque Purification of Bluetongue Virus Serotype-4 (BTV-4). Int.J.Curr.Microbiol.App.Sci. 7(04): 2837-2844. doi: https://doi.org/10.20546/ijcmas.2018.704.323 